
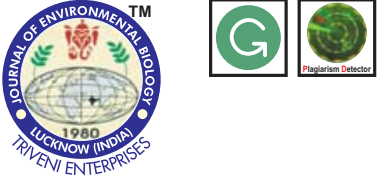

DOI: https://doi.org/10.22438/jeb/38/3/MS-256

\title{
Study on retail fish markets: Possible occurance and transmission of emergeing pathogen from faecal indicators
}

ISSN: 0254-8704 (Print) ISSN: 2394-0379 (Online) CODEN: JEBIDP
JEB Journal of

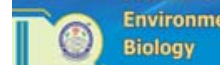

Authors Info

S. Visnuvinayagam ${ }^{1 *}$, L.N. Murthy², P.Viji ${ }^{3}$ and G.K. Sivaraman ${ }^{4}$

${ }^{1}$ Microbiology Division, Mumbai Research Centre of CIFT, Vashi-400 703, India

${ }^{2}$ Fish Processing Division, Mumbai Research Centre of CIFT, Vashi-400 703, India

${ }^{3}$ Fish Processing Division, Vishakhapatnam Research Centre of CIFT, Vishakhapatnam, Andra Pradesh-530 003, India

${ }^{4}$ Microbiology Division, Veraval Research Centre of CIFT, Vashi, Veraval-362 269, India

${ }^{*}$ Corresponding Author Email : visnuvinayagam@yahoo.co.in

Key words

E. coli,

Faecal indicators,

Faecal streptococci,

Sulphite reducing clostridia

Publication Info

Paper received: 09.02 .2016

Revised received : 23.10.2016

Re-revised received : 27.10.2016

Accepted:09.11.2016

\section{Abstract}

Aim: Most of the Indian consumers hitherto invouge prefer to procure the fish in retail markets despite of its poor unhygienic condition. Hence, multiyear environmental study was carried out to scrutinize the hygienic status by faecal indicator estimation in retail markets of Navi Mumbai region.

Methodology: In total, 159 marine fish were collected and analysed for estimation of aerobic plate count and faecal indicator bacteria viz., E. coli, faecal streptococci and sulphite reducing clostridia.

Results: Aerobic plate counts of all fish were within the limit; but the level of $E$. coli was higher in retail fish i.e., $22.4 \%$. The average level of $E$. coli, faecal streptococci and sulphite reducing clostridia were 14, 31, 15 cfu $^{-1}$, respectively. Higher ratio was observed between the faecal streptococci and E. coli i.e., 1:0.45.

Interpretation: Fish in retail markets harbour noteworthy number of faecal indicator bacteria which indicates considerable number of faecal contamination and poor hygienic status of the retail market. Repeated use of same water for washing fish may be reason for the elevated level of contamination. So, cleaning of fish with potable water may reduce contamination. In addition, these retail markets need to be monitored by the controlling authority at regular intervals with stringent control policy in order to provide safe seafood.

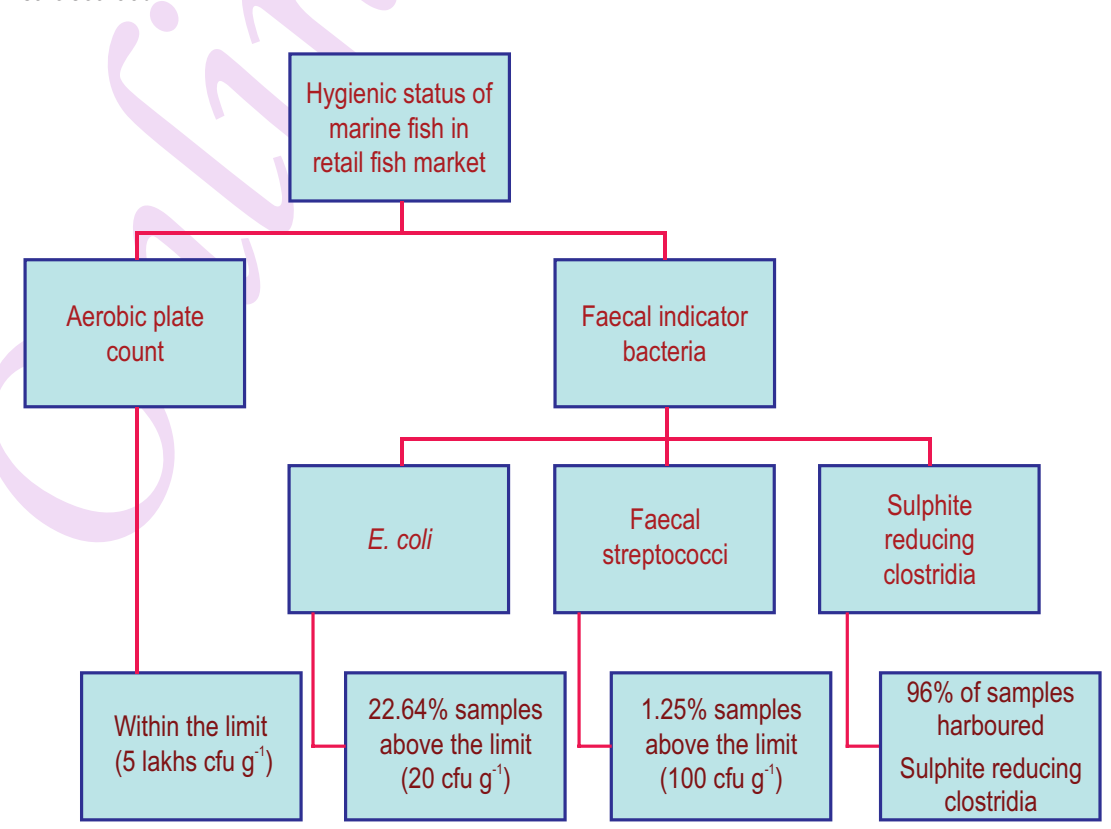




\section{Introduction}

Faecal indicator bacteria are index organisms that generally exist as commensal in the intestine of warm blooded animal; but, not in fish (Huss, 1994). Hence, the presence of these indicators in fish show definite faecal contamination (Kulshrestha and Sharma, 2006; Sharma and Chaturvedi, 2007). E. coli, faecal streptococci and Sulphite reducing clostridia are considered as important indicators for assessment of faecal contamination (Tyagi et al., 2006). Presence of mere faecal indicator bacteria in fish is not directly connected with pathogenic bacteria; but, there is high chance of occurrence of pathogenic bacteria in water bodies. Hence, existence of these faecal indicator bacteria in fish needs to be considered very critically to control the waterborne pathogenic bacteria/virus/parasitic oocyst contamination in fish (Ashbolt et al., 2001).

E. coli is a primary indicator for faecal contamination; abundant in warm blood animal faeces. So, $E$. coli is considered as a sole indicator for faecal contamination (Tallon et al., 2005). But, it exists in environment for short period and rapidly destroyed while freezing the food materials (Huss, 1994). Another group of faecal indicator bacteria viz. faecal streptococci is being used to monitor the potable water resources (EC, 1998; Krishnan et al. 2007). It has better survivability in environment and in freezing temperature thus make the bacteria can stay longer period in environment than E. coli (Huss, 1994). Around $84 \%$ of sewage contaminated polluted water sources contain faecal streptococci; hence, it is considered as true faecal indicators. The term faecal streptococci and Enterococci are used alternatively because Enterococci are considered as sub set of faecal streptococci. Recent report says that these faecal streptococci are not only an indicator bacteria but also a pathogenic bacteria i.e., Enterococcus faecalis and Enterococcus faecium are responsible for endocarditis, intra-abdominal infection, surgical wound infection and urinary tract infections in human (Ross, 1998; Barrell et al., 2000). It has also been recorded that $E$. faecalis and $E$. faecium are regularly isolated from cheese, fish, sausages, minced beef and pork (Foulquie et al., 2006; Klein, 2003). E. faecalis and $E$. faecium are the most prevalent species isolated from humans clinical cases. E. faecium is responsible for most Vancomycin-Resistant Enterococci infections.

Sulphite reducing clostridia are group of bacteria that reduce sulphate to sulphite; presence of these sulphite reducing clostridia in water resources indicate the remote faecal contamination. Since sulphite reducing clostridia spores are highly resistance in nature and withstand sanitation, it is used to evaluate the virus, cyst inactivation and to assess the effect of sanitation in drinking water disinfection processes (WHO, 1996; Borrego et al, 2002).

In the past year, faecal streptococci are considered as an indicator for faecal contamination; but, recent research report from hospitals are frequently associated with the faecal streptococci as a prime pathogenic responsible of urinary infection and other critical diseases. Since, fish are handled by various persons, it has been found that a considerable number of faecal streptococci in fish and elevated level of faecal streptococci in some of the fish and shell fish. But, permissible limits/standards have not yet been defined by Food Control Authority in India, as well as international for faecal streptococci. In case of other faecal indicators such as $E$. coli and $C$. perfringens, permissible limit has been defined by Indian Food Control Authority i.e., $20 \mathrm{cfu} \mathrm{g}^{-1}$ and absence in $25 \mathrm{~g}^{-1}$ respectively (FSSAI 2012). Considering the emergence of pathogenic Faecal streptococci, in the present study Faecal streptococci and other Faecal Indicator Bacteria were investigated in marine fish and shell fish, available in retail markets with reference to different species, and discussing about the possible source of contamination and prevention. Since, most of the Indian consumers prefer local retail outlet for the procurement of fish, the present study mainly focused on the local retail markets.

\section{Materials and Methods}

Fish sample from retail fishery market : In total, 159 marine water fish were collected randomly, based on the availability of the fish in different fish markets (Table 1) in a sterile polythene bags with ice and brought to laboratory within four hours. Name of the collected fish and shell fish are as follows Chirocentrus dorab, Johnius dussumieri, Epinephelus sp., Congresox talabonoides, Tylosurus crocodilus, Parastromateus niger, Lates calcarifer, Rastrelliger kanagurta, Mugil cephalus, Sillago sihama, Nemipterus japonicus, Eleutheronema tetradactylum, Dasyatis sp., Sardinella longiceps, Scomberomorus sp., Penaeus sp., Pampus argenteus, Cynoglossus sp., Loligo duvauceli.

Aerobic plate count : Twenty five grams of fish sample was aseptically taken from upper part of the fish and transferred to $225 \mathrm{ml}$ of $0.1 \%$ peptone saline; the fish meat was then blended in a stomacher (Seaward, UK) for $2 \mathrm{~min}$. The blended material was serially diluted upto $10^{-6}$ dilution; then, $0.5 \mathrm{ml}$ of sample was transferred to Tryptone Glucose Beef Extract agar (Hi Media, \#M791) plates and spread over the surface and incubated at $35^{\circ} \mathrm{C}$ for 2 days for aerobic plate count enumeration (APHA, 2015).

Escherichia coli : Enumeration of E. coli was carried out by ISO, 9308-1 (ISO, 1990) with slight modification i.e., $0.5 \mathrm{ml}$ of serially diluted fish sample was transferred to Modified Tergitol-7 (Hi Media, \#M6161) plates supplemented with $0.25 \mathrm{ml}$ of $1 \%$ Triphenyl Tetrazolium Chloride (Himedia, FD057) and spread over the surface; then, all the plates were incubated at $35^{\circ} \mathrm{C}$ for 24 hrs. Flat dry yellow colonies with red tinge were further streaked over eosin methelene blue agar plates; after incubation, colonies showing greenish metallic sheen were further subjected to IMViC for further confirmation (ISO, 1990). 
Faecal streptococci : The faecal streptococci were enumerated, based on the pour plated method. One $\mathrm{ml}$ of dilute sample from each test tube was transferred to sterile empty petri plates. Then Kenner faecal (KF) streptococcal agar base (Hi Media, \#M248) was boiled and cooled to $48^{\circ} \mathrm{C}$ then supplemented with $1 \mathrm{ml}$ of $1 \%$ of 2,3,5-triphenyl-2H-tetrazolium chloride (FD057). Finally, agar medium was poured in petri plate containing $1 \mathrm{ml}$ of diluted fish meat and rotated firmly for uniform mixing. After the plates were dried, $5 \mathrm{ml}$ of KF agar medium was overlaid on the surface of each plate and allowed to dry in room temperature. All the plates were then incubated at $35^{\circ} \mathrm{C}$ for $48 \mathrm{hrs}$. Brown colonies surrounded by a halo zone subjected to biochemical test for further confirmation (APHA, 2015; Sugumar et al., 2008).

Sulphite reducing clostridia : Sulphite reducing clostridia numbers were determined by a three tube MPN technique using Differential Reinforced Clostridial Broth (DRCB) (M549, Himedia). All black colour tubes were confirmed by streaking on to Tryptose Sulfite Cycloserine (TSC) agar and the characteristic colonies were again confirmed by biochemical reactions as described by Collee et al. (1996).

\section{Results and Discussion}

Aerobic plate count for the collected samples were below $5,00,000 \mathrm{cfu} \mathrm{g}^{-1}$ and ranged between 2,000 -4,00,000 $\mathrm{cfu} \mathrm{g}^{-1}$. But, $22.64 \%$ of fish samples harboured higher level of $E$. coli i.e., more than the recommended level $\left(20 \mathrm{cfu} \mathrm{g}^{-1}\right)$; an average of $14.62 \mathrm{cfu}$ $\mathrm{g}^{-1}$ of $E$. coli was noticed in the fish of retail fish market. Higher level of $E$. coli (56.67 $\mathrm{cfu} \mathrm{g}^{-1}$ ) and sulphite reducing clostridia (51.67 cfu $\mathrm{g}^{-1}$ ) was noticed in Shrimp species (Penaeus sp.). Higher level of faecal streptococci $\left(60 \mathrm{cfu} \mathrm{g}^{-1}\right)$ was noticed in seer fish. Average of 31.93 and $15.80 \mathrm{cfu} \mathrm{g}^{-1}$ was observed for the faecal streptococci and sulphite reducing clostridia respectively (Table 1).

Correlation coefficient was used in the study to assess the impact of faecal indicator on aerobic plate count using Excel, Window 7 and it was found that there is no significant correlation was observed between and aerobic plate count and faecal indicator bacteria (Table 2). The ratio between the faecal streptococci and $E$. coliwas 1:0.45.

Aerobic plate count is a prime indicator of food spoilage; even though aerobic plate counts are not hazardous to human, it indicates the level of spoilage. As per Indian and international standard, the limitation for aerobic plate count in fish was $5,00,000$ cfu g $^{-1}$ (FSSAI, 2012; IS, 1978; ICMSF, 1986). In the present study, the aerobic plate count level of all the collected samples were within $5,00,000 \mathrm{cfu} \mathrm{g}^{-1}$ the reason may be that fishes are procured on the basis of freshness index such as color, appearance and firmness.

Eventhough, aerobic plate count was within the limit, there is a huge possibility of presence of hazardous microorganism in the fish. Because, most of the fish were exposed to contamination while handling/processing. Indian Food Control Authority has given clear guidelines such as the fish sample should not have $E$. coli higher than $20 \mathrm{cfu} \mathrm{g}^{-1}$. In the present investigation among 159 samples, 36 samples consisted of higher $E$. coli i.e., $22.64 \%$ of the samples had higher $E$. coli count than the recommended level. Among the collected seafood, shrimp species were highly contaminated (Table 1), which might be due to the use of contaminated water in the fish market, and led to the accumulation of $E$. coli between the shrimp shell and the body, thus increase the contamination. On an average around 14 cfu $\mathrm{g}^{-1}$ of $E$. coli were present in the fish of retail market, which indicates a considerable number of faecal contaminations were observed in the retail markets.

Even though, faecal streptococci are the important indicator, there is no international limit in fish/ meat. But, European council recommended level of for Enterococcus sp. (sub set of faecal streptococci) in potable water is $0 / 250 \mathrm{ml}$ (EC, 1998); but not for food or fish. In India, Bureau of Indian Standard (BIS) recommends that level of faecal streptococci should not exceed $100 \mathrm{cfu} \mathrm{g}^{-1}$ of fish (IS: 4780 - 1978). So, as per Indian standard IS-4780- 1978 (IS, 1978) in the present investigation two samples were exceeding the recommended limit of faecal streptococci i.e., 100cfu g-1 (IS: 4780 - 1978). In India, implementing and monitoring authority viz., Food safety standards authority of India (FSSAI) has not mentioned the faecal streptococci level in fish. Recent dreadful report suggested that, the Enterococcus species viz. E. faecalis and E. faecium are responsible for endocarditis, intra-abdominal infection, surgical wound infection, and urinary tract infections, endocarditis and meningitis in humans (Ross, 1998; Barrell et al., 2000). E. faecalis recorded as a main cause of life-threatening infections in humans, especially in the nosocomial (hospital) environment with high levels of antibiotic resistance (Ryan and Ray, 2004). Around $30 \%$ to $90 \%$ of root canal-treated teeth are infected with $E$. faecalis. About nine times increase in recurrence of $E$. faecalis as a secondary infection in root canal infection than primary infections (Molander et al., 1998; Rocas et al., 2004). Vancomycin resistant Enterococci i.e., E. faecalis is an emerging problem in worldwide in the hospital, it is resistant to most commonly used antibiotics (Amyes et al., 2007).

Presence of $E$. faecalis in fish can be transferred to the handlers during handling process. In addition, these faecal streptococci are heat resistant and it can withstand pasteurization, temperature, it may survives in partial cooking and it will not be affected by ingestion (Sorensen et al., 2001); thus makes the bacteria to spread easily to handlers and consumers. So, proper and hygienic handling is needed for fish handlers and consumers; because, the present study confirms the presence of noteworthy numbers of faecal streptococci in retail fish markets i.e., average of $31 \mathrm{cfu} \mathrm{g}^{-1}$ of faecal streptococci was observed in 


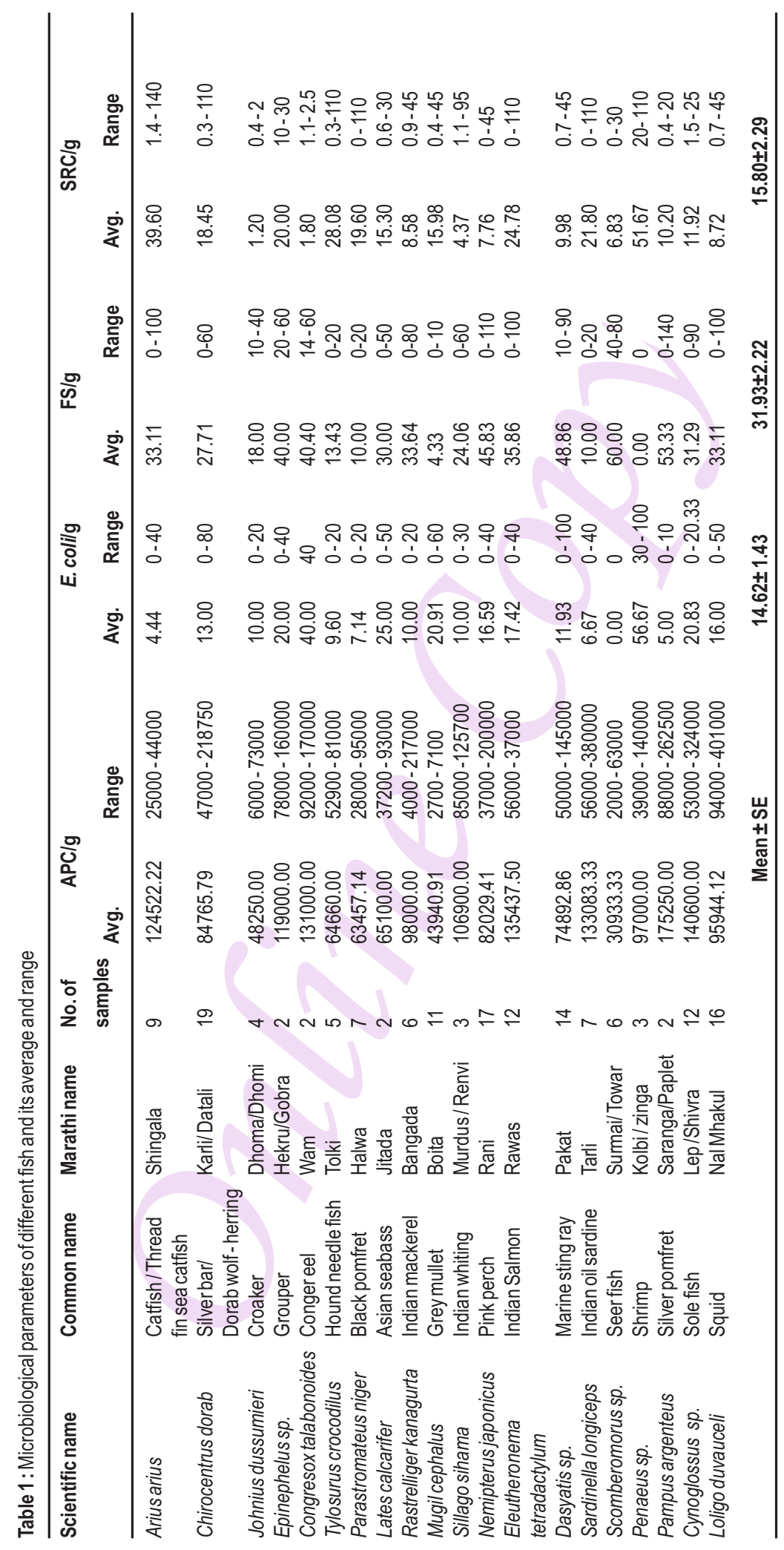


Table 2 : Correlation between APC, S. aureus and Faecal indicators

\begin{tabular}{lllll}
\hline $\begin{array}{l}\text { APC and Faecal } \\
\text { indicator bacteria }\end{array}$ & APC & E. coli & FS & SRC \\
\hline APC & 1 & & & \\
E. coli & 0.065914 & 1 & & \\
FS & 0.212045 & 0.228605 & 1 & \\
SRC & 0.253649 & 0.124246 & 0.076177 & 1 \\
\hline
\end{tabular}

the retail fish markets. Since, $E$. faecalis is major concern in the Enterococcus genus; enumeration of $F$. faecalis will be sufficient instead the enumeration of total Enterococcus/faecal streptococci in fish.

Sulphite reducing clostridia are the group of Clostridia includes mainly Clostridium perfringens, C. bifermentans, C. difficile, C. sporogenes, C. botulinum and C. septicum (Kouassi et al., 2011). Among the group, C. perfringens is a key species and commonly found in human and animal intestine. Since, $C$. perfringens is specific and more pathogenic, recent EC directive has amended the regulation i.e., C. perfringens has to be analysed in place of sulphite reducing clostridia. Previous EC directive recommended that the level of sulphite reducing clostridia should be absent in $20 \mathrm{ml}$ of potable water; but the recent 98/83/EC Directives recommend absence of $C$. perfringens in $100 \mathrm{ml}$ of potable water (Barrell et al., 2000). In the present study shows that among the 159 sample 154 samples contained sulphite reducing clostridia (Table 1); hence, there is huge possibility of $C$. perfringens in most of the samples; thus attributes that most of the fishes are contaminated with faecal materials. Since, sulphite reducing clostridia can withstand the cooking temperature and other food processing techniques, most of the fish still carry the sulphite reducing clostridia even after cooking/processing or any other preservation method. Hence, the hygienic handling practices have to be followed to avoid the sulphite reducing clostridia/C. perfringens in seafood.

In the present investigation, twenty different types of fish and shell fish were evaluated for presence of faecal indicator bacteria (Table 1). The outcome, shrimps samples were harbouring elevated level of $E$. coli and sulphite reducing clostridia. The reason for the elevated level of $E$. coli and sulphite reducing clostridia in shrimp may due to either contamination in pond (brackish water) or repeated use of contaminated water for cleaning of shrimps in the retail market. The unique feature of shrimp exoskeleton; especially the below the exoskeleton may entrap most of the contaminant, thus favours the high level of $E$. coli or sulphite reducing clostridia in shrimp. Eventough fishes encounter the same contaminated water; it may not accumulate as like shrimp. So, results suggest that most of the shrimp samples are highly prone for faecal contamination. In case of seer fish higher number of faecal streptococci with completely devoid of $E$. coli. Perhaps, seer fishes are more in demand and fetch higher cost in the retail markets; transported/retailer might have stored in the fish below the freeing point to retain the better quality of fish. The below freezing temperature might have destroyed the E. coli. Similarly, the costly/high demand fishes viz. black pomfret and silver pomfret had lower level of $E$. coli.

Butniaux and Mossel (1961) reported that per gram of faecal matter contains $40 \times 10^{6}$ coliform, $4 \times 10^{6}$ of $E$. coli and $4 \times 10^{6}$ Enterococcus sp. Hence, Presence of 10 number of $E$. coli in the food is equal to contamination by $2.5 \mathrm{~g}$ faecal materials in fish. They also observed that ratio between the Enterococcus with $E$. coli is 1:0.1. But, in the present study faecal streptococci with $E$. coli ratio was $1: 0.45$ i.e., very high level of $E$. coli in fish samples, which is possible due to multiplication of $E$. coli in fish samples. So, the present study clearly indicates that the marine fish samples favour the multiplication of the $E$. coli.

Since marine environment is free of faecal indicator bacteria, most of the contamination take place in post-harvest handling (Visnuvinayagam et al., 2015a; 2015b; Sivaraman et al., 2016a; 2016b; Murugadas et al., 2016), these contaminations starts from the un-cleaned fish storage tank, contaminated water used for cleaning of the fish in harbours and retail market. Repeated use of same water for cleaning of the fish in retail market would play a major factor responsible of the contamination of fish (Visnuvinayagam et al., 2015b). Correlation co-efficient was carried out between aerobic plate count and within faecal indicator bacteria (Table 2); the study found that there is very poor correlation was observed between the aerobic plate count and faecal indicator bacteria i.e., 0.07 to 0.25 . Similarly poor correlation was observed between the faecal indicator bacteria i.e., 0.07 to 022 , which may due to that the distribution of the faecal indicator bacteria in the fish flesh/surface may not be uniform and multiplication of faecal indicator in fish. High level of E. coli and sulphite reducing clostridia in the shrimp species, high number of faecal streptococci with absence of $E$. coli seer in the present investigation is need to be confirmed by analysing more number of samples.

It is concluded that $22.4 \%$ of the fish available in the fish market are unfit for human contamination due to excess level of $E$. coli in the fishes. Contamination can be reduced by providing a potable water to clean the fish to remove the surface adhered bacteria and retail markets need to be monitored by the controlling authority at regular interval with stringent control policy to sell safe seafood. So, fish handlers should aware of good hygienic handling practices of seafood.

\section{Acknowledgments}

The microbiological work carried out by Thriveni G. Adiga, Assistant Chief Technical officer of Mumbai Research Centre of CIFT is thankfully acknowledged. The author also thank the Director, ICAR-CIFT, Cochin for funding the project. 


\section{References}

Amyes, S.G.: Enterococci and Streptococci. Int. J. Antimicrob. Agents, 29, S43-52 (2007).

APHA: American Public Health Association, Yvonne Salfinger and Mary Lou Tortorello Compendium of Methods for the Microbiological Examination of Foods. $5^{\text {th }}$ Edn., APHA, Washington, D.C. (2015).

Ashbolt, N.J., O.K. Willie Grabow and S. Mario: Indicators of microbial water quality. IWA Publishing, Alliance House, 12 Caxton Street, London, UK (2001).

Barrell, R.A., P.R. Hunter and G. Nichols: Microbiological standards for water and their relationship to health risk. Commun. Dis. Public Hlth., 3, 8-13 (2000).

Borrego, J.J., D. Castro and M.J. Figueras: Faecal streptococci/ enterococci in aquatic environments. Encyclopedia of Environmental Microbiology (Ed.: G. Bitton). John Wiley and Sons, New York, NY, USA; pp. 1264-1278 (2002).

Butniaux, R. and D.A.A. Mossel: The significance of various organisms of faecal origin in foods and drinking water. J. App. Bacteriol., 24, 353364 (1961).

Collee, J.G., A.G. Fraser, B.P. Marmion and A. Simmons: Practical Medical Microbiology. $14^{\text {th }}$ Edn., Churchill Livingstone (1996).

EC: Council Directive 98/83/EC of 3 November 1998, on the quality of water intended for human consumption. L 330/32 EN Official Journal of the European Communities (1998).

Foulquie, M.R., P. Sarantinopoulos, E. Tsakalidou and L. De Vuyst: The role and application of enterococci in food and health. Int. J. Food Microbiol., 106, 1-24 (2006).

FSSAl: Lab Parameters for Imported Food and Methods for Standardization, F.No.06/FSSAl/Import Issue. Ministry of Health and Welfare, third floor FDS Bhawan, New Delhi (2012).

Huss, H.H.: Traditional Microbiological Quality Control, in Assurance of seafood quality. FAO Fisheries Technical Paper - 334 (1994).

ICMSF: International Commission on Microbiological Specifications for Foods, Micro-organisms in Foods 2 -Sampling for Microbiological Analysis: Principles and Specific Applications. $2^{\text {nd }}$ Edn., Blackwell Scientific Publications, Oxford, England (1986).

IS: Indian standard 4780-1978 (Reaffirmed 2000), Indian standard specification for Pomfret, fresh (First Revision) Fish and Fishery Products Sectional Committee, AFDC 27. Indian Standard Institution, New Delhi (1978).

ISO: International Organization for Standardization (ISO), 1990, Draft ISO/DIS 9308-9311 (1990)

Klein, G.: Taxonomy, ecology and antibiotic resistance of Enterococci from food and the gastro-intestinal tract. Int. J. Food Microbiol., 88, 123-131 (2003).

Kouassi, K.A., A.T. Dadie, Z.Y. Nanga, K.M. Dje and Yao: Prevalence of sulfite reducing Clostridium species in barbecued meat in Abidjan, Côte d'Ivoire. J. Appl. Biosci., 38, 2518-2522 (2011).

Krishnan, R.R., K. Dharmaraj and B.D. Ranjitha Kumari: A comparative study on the physico-chemical and bacterial analysis of drinking, borewell and sewage water in the three different places of Sivakasi. J. Environ. Biol. 28, 105-108 (2007).
Kulshrestha, H. and S. Sharma: Impact of mass bathing during Ardhkumbh on water quality status of river Ganga. J. Environ. Biol., 37, 437-440 (2006).

Molander, A., C. Reit, G. Dahlen and T. Kvist: Microbiological status of root filled teeth with apical periodontitis. Int. Endodontic J., 31, 1-7 (1998).

Murugadas, V., T.C. Joseph and K.V. Lalitha: Distribution of pathotypes of Escherichia coli in seafood from retail markets of Kerala, Indian. Ind. J. Fish., 63, 152-155(2016).

Rocas, I., J. Siqueira and K. Santos: Association of Enterococcus faecalis with different forms of periradicular diseases. J. Endod., 30, 315-320 (2004).

Ross, P.W.: Streptococcus and Enterococcus. In: Microbiology: A Guide to Microbial Infections: Pathogenesis, Immunity, Laboratory Diagnosis and Control. $15^{\text {th }}$ Edn., Hong Kong, China (1998).

Ryan, K. J. and C.G. Ray: Sherris Medical Microbiology. $4^{\text {th }}$ Edn., McGraw Hill, pp. 294 - 295 (2004).

Sharma, A. and A.N. Chaturvedi: Population dynamics of Vibrio species in the river Narmada at Jabalpur. J. Environ. Biol., 28, 747-751 (2007).

Sivaraman, G.K., S, Visnuvinayagam, A.K. Jha, V. Renuka, S. Remya, and $D$. Vanik: Assessment of microbial quality of fish processing industrial effluent in bar-mouth at Bhidia landing site, Veraval, Gujarat, India. J. Environ. Biol., 37, 537-541(2016).

Sivaraman, G. K., S. Visnuvinayagam, A.K. Jha, S. Remya, V. Renuka, K. Ajeesh and D. Vanik: Molecular divergence and identification of Aspergillus species in dry fishes of Gujarat, India. In: Proceedings of the National Academy of Sciences, India Section B: Biological Sciences, 1-11 (2016). (10.1007/s40011-016-0779-y)

Sorensen, T.L., M. Blom, D.L. Monnet, N. Frimodt-Møller, R.L. Poulsen and F. Espersen: Transient intestinal carriage after ingestion of antibiotic-resistant Enterococcus faecium from chicken and pork. New Eng. J. Med., 345, 1161-1166 (2001).

Sugumar, G., B. Chrisolite, P. Velayutham, A. Selvan and U. Ramesh: Occurrence and seasonal variation of bacterial indicators of faecal pollution along Thoothukudi coast, Tamil Nadu. J. Environ. Biol., 29, 387-392 (2008).

Tallon, P., B. Magajna, C. Lofranco and K. Leung: Microbial indicators of fecal contamination in water: A current perspective. Water Air Soil Pollut., 166, 139 - 166, (2005).

Tyagi, V.K., A.K. Chopra, A.A. Kazmi and A. Kumar: Alternative microbial indicators of faecal pollution: Current perspective. Iran J. Environ. Hith. Sci. Eng. 3, 205-216 (2006).

Visnuvinayagam, S., P. Viji, P. K. Binsi, R. Chakrabarti, T. Adiga, C. G. Joshy and K. V. Lalitha: Effect of monsoon on sulphite reducing Clostridia levels in fish from retail market in Maharashtra. Fish. Technol., 52, 198-201 (2015a).

Visnuvinayagam, S., Toms C. Joseph, V. Murugadas, R. Chakrabarti and K. V. Lalitha: Status on methicillin resistant and multiple drug resistant Staphylococcus aureus in fishes of Cochin and Mumbai coast, India. J. Environ. Biol., 36, 571, (2015b).

WHO: World Health Organization, Guidelines for drinking water quality. Vol. 2, $2^{\text {nd }}$ Edn., Health criteria and other supporting information, World Health Organization, Geneva (1996). 